\title{
References
}

Brass, Paul R. (2003) The Production of Hindu-Muslim Violence in Contemporary India. New Delhi: Oxford University Press.

Varshney, Ashutosh (2002) Ethnic Conflict and Civic Life. New Haven, CT: Yale University Press.

THOMAS BLOM HANSEN is Professor of Anthropology in the Department of Anthropology, Yale University. Address: Department of Anthropology, Yale University, PO Box 208277, New Haven, CT 06520-8277. [email:Blomhansent@hotmail.com; thomasblom.hansen@yale.edu]

\section{Review of Paul Brass}

\author{
A.R. MOMIN \\ University of Mumbai
}

It can hardly be disputed that communalism, particularly in its most horrifying manifestation in Hindu-Muslim riots, poses the gravest threat to the cohesiveness and stability of society and state in India. The social, economic and human costs of communal violence are enormous and in fact incalculable. There is an unfortunate dearth of systematic, intensive and empirically based studies on communal violence; most of the studies on the subject tend to be rather descriptive and lack analytical rigour and theoretical refinement. This book (Brass, 2003), based on an intensive case study of communal violence in the riot-prone town of Aligarh in northern India carried over a period of nearly 38 years, makes a valuable contribution to the systematic study of communal violence in contemporary India.

Brass argues that persistent communal violence in Aligarh, as elsewhere in the country, is embedded in a discourse of communalism which is premised on a deliberate and calculated accentuation of religious and cultural differences between Hindus and Muslims, hostility towards Muslims, and militant Hindu nationalism. Riots, according to him, are not spontaneous occurrences which can be facilely explained in terms of mob fury. They are essentially a planned, orchestrated and institutionalized phenomenon. Brass argues that there exists at sites of endemic communal violence an 'institutionalized riot system' which works as a central factor in the genesis and persistence of communal riots. This system, which is 
nourished and sustained by the discourse of communalism, involves a multiplicity of roles and a network of relations between specific individuals, economic interests, organizations, criminals, politicians, and the police. Brass maintains that there is a close linkage between communal violence and the political process, especially electoral competition and political mobilization.

In seeking to explain the persistence of communal violence Brass draws on a functionalist theory and argues that communal riots have functional utility and benefits for a wide range of groups and organizations in society, particularly the Bharatiya Janata Party (BJP) and other political organizations affiliated to the Rashtriya Swayamsevak Sangh (RSS). He points out that the Hindu-Muslim divide and polarization, which is rooted in the discourse of communalism and militant Hindu nationalism, has been extremely valuable to the political fortunes of the BJP.

In keeping with the view that riots are a product of planning and strategy, Brass speaks of three stages of riot production: preparation, actual enactment, and post-hoc explanation or interpretation. He provides, within the conceptual framework sketched out in the foregoing, a detailed explication and analysis of the pattern and dynamics of communal violence in Aligarh since Independence. The focus of the study, he emphasizes, is on how riots are produced, rather than on why they happen. The book contains some highly perceptive observations and penetrating insights into the dynamics of communal violence. It is written in a lucid, straightforward and candid style.

While Brass's systematically collected and enormous data on Aligarh and his analysis of the varied dimensions of communal violence are immensely valuable, his conceptual and methodological approach leave something to be desired. Though he is critical of causal analysis and emphasizes the central role of human agency in social processes, one can nevertheless notice a lurking positivistic propensity in his generalizations. Thus, he frequently talks about causal linkages, such as the 'direct causal link between riots and electoral/political competition' (p. 33). This nomothetic predilection is also betrayed in his hope that the findings of the book can be generalized to 'other parts of India and to other times and places in the world' (Preface, emphasis added). Apparently, Brass assumes or implies that all forms of violence in the world are fundamentally alike, and that they have basically the same dynamics, which can be explained in terms of a few parameters (or laws) having universal applicability. This positivistic assumption is a matter of belief rather than an empirically verifiable proposition. It disregards the enormous variations in the patterns and manifestations of violence in different social, cultural and political contexts and in their aetiology and motivations.

Drawing on the functionalist perspective, Brass argues that large-scale riots serve the interests of particular individuals, groups, organizations and 
'even society as a whole in concrete, useful ways that are beneficial to them' (pp. 23-4, emphasis added). One can readily understand and agree that communal riots have functional utility for a wide range of groups and organizations that stand to benefit from them. However, one is at a loss to understand how riots could have functional utility or benefits for society as a whole. Evidently, riots bring about devastation, disruption and disharmony in the larger society. In other words, they are dysfunctional to society. Robert Merton, whose functionalist paradigm undergirds Brass's conceptualization, has clearly stated that certain forms of culture or social processes may have functional as well as dysfunctional consequences. Undoubtedly, the functionalist perspective has some heuristic value but, as the eminent British anthropologist Sir Edward Evans-Pritchard cautioned many years ago, in its extreme form functionalism often leads to absolute relativism, a crude teleology, and a naïve determinism.

In tune with the functionalist perspective, Brass focuses on persistence and continuity and ignores the role of changing social and political contexts. The 'institutionalized riot system' may undergo radical changes over some period of time or may become ineffective or may even break up and disintegrate under the pressure of an efficient, impartial and forceful local administration, a vigilant local leadership, and concerted civic action. Brass refers to a key player in communal riots, described as a 'conversion specialist', who has a knack of turning a mere local, trivial incident into a potent tool for instigating a riot. But he fails to consider the possibility that the machinations of the 'conversion specialist' may well be thwarted by a watchful and responsible local administration with the cooperation of a vigilant local leadership. This has in fact happened in some places - in Bhiwandi (Maharashtra) in 1992 and in Surat (Gujarat) in 2002. Unfortunately, Brass does not take sufficient cognizance of the potentially effective role of the local administration and civic action in averting or preventing a riot, though he makes passing references to it (pp. 142, 169-70).

Brass's study raises, inadvertently, some methodological problems. The case study method employed in the study undoubtedly has the advantage of providing an in-depth, micro-view of the complexity and dynamics of specific social situations. However, it is not free from drawbacks. One tends to take one's field or area of study as a kind of yardstick of comparison and, on the basis of it, makes rather sweeping generalizations and extrapolations. Thus, Brass maintains that he is seeking an explanation for the persistence of communal violence in Aligarh which in turn can be generalized as an explanation for recurring riots elsewhere as well' (p. 38). Similarly, he asserts that the political context of communal violence is decisive, that it is riots that produce communal solidarity, not electoral politics that produces riots (pp. 367-71). Looking at the Gujarat carnage of 2002, one is inclined to believe that electoral politics, among other factors, may well lead to a riot.

It may be pointed out that generalizations based on a single case study 
ignore the enormous diversity and complexity of Indian society in general and of riot-prone sites and riot situations in particular. Furthermore, such generalizations are usually made within a static framework and therefore do not take due cognizance of changing social and political contexts. In many respects, Aligarh has a rather unique character as a town and as a site of endemic communal violence, different from other riot-prone towns and cities. If one focuses on Aligarh, where the Hindu-Muslim divide and communal riots have been conspicuous, one would invariably be led to ask the question that Brass addresses: how riots persist and recur with such frequency and intensity. However, if one were to focus on a different riot-prone town or city - such as Surat or Bhiwandi, which have experienced violent Hindu-Muslim clashes as well as long periods of peaceful coexistence - one may be led to ask an altogether different, and far more important, question: how can riots be effectively averted or prevented?

Brass emphasizes, exaggeratedly, that riots are wholly a product of rational planning and preparation. To buttress his argument, he draws on the dramaturgical perspective and maintains that riots are 'dramatic productions' (p. 369). He elaborates:

The people of Aligarh, like devotees of theatre, are kept in a state of readiness for the next production (riot) through advertising of all kinds of trivial incidents that hold the promise of a great drama to follow ... each production involves audience participation. (p. 358)

The contrasts between a riot and drama are too stark and glaring. While watching theatre brings great joy and amusement, riots bring nothing but fear, anxiety and despair for the people. Furthermore, the involvement of the audience in theatre is wilful, whereas large numbers of people are caught up in the riot situation against their will. The characterization of Hindu-Muslim riots in the metaphor of drama or theatre is not only an over-simplification but a grotesque distortion of communal violence.

\section{Reference}

Brass, Paul R. (2003) The Production of Hindu-Muslim Violence in Contemporary India. New Delhi: Oxford University Press.

\footnotetext{
A.R. MOMIN is Professor of Cultural Anthropology and Head of the Department of Sociology, University of Mumbai. Address: Department of Sociology, University of Mumbai, Kalina, Mumbai 400 098, India. [email:armomin@mu.ac.in]
} 